\title{
The Effect of Additive (Herbal Medicine) on The Red Blood Profile in Laying Hens
}

\author{
Maldini. T. P, Sugiharto dan Isroli \\ Faculty of Animal Husbandry and Agriculture, Universitas Diponegoro \\ Jl. Prof. H. Soedarto, S.H. Tembalang, Semarang, Indonesia 50275 \\ Corresponding author: tanjungpuspamaldini@gmail.com
}

\begin{abstract}
This research aims to determine the amount of erythrocytes, hemoglobin levels and hematocrit levels of laying hens which are given additional herbal medicine in feed by adding herbs. Jamu consists of a mixture of temulawak, lempuyang, ginger, bitter and turmeric, each in the same portion of $20 \%$. A total of 40 laying hens aged 35 weeks are kept for one month. The experimental design uses a completely randomized design (CRD), with 4 treatments and 5 replications so that there are 20 units of experiment, each unit contains 2 chickens with additional feed, namely T0 (basal feed), T1 (basal feed plus $0.5 \%$ herbal medicine), T2 (basal feed plus $1 \%$ herbal medicine), T3 (basal feed plus $1.5 \%$ herbal medicine). Blood sampling was done at the end of the research to calculate the amount of erythrocytes, hemoglobin levels and hematocrit levels. The results showed hematocrit levels in chickens that were added additional herbs in the ration both at $\mathrm{T} 1, \mathrm{~T} 2$ and $\mathrm{T} 3$ were different $(\mathrm{P}<0.05)$ with chickens that were not given additional herbs in the ration. The conclusion from the research conducted is the addition of herbal medicine can increase the profile of red blood in laying hens.
\end{abstract}

Keywords: Blood profile, herbs, laying hens.

\section{Introduction}

Laying hens is one of the poultry potentials in Indonesia which is specially cultivated to produce eggs commercially (Setiawati et al., 2016). In Indonesia, the layer of laying hens that are widely cultivated is the Lohmann strain (Rahayu et al., 2011).

Farmers generally increase their livestock production by using antibiotics, but currently the use of antibiotics has been banned in many countries, therefore alternative antibiotic substitutes are needed. An alternative use of antibiotics currently favored by farmers is the use of herbs, which have a positive effect on the body's immunity to disease. Livestock herbs can be made from ginger, lempuyang, ginger, bitter, which can improve the performance of laying hens, control disease in chickens and maintain livestock productivity and can improve the performance of red blood profiles (Damayanti, 2005). Red blood profile in general can be used as an indicator of the nutritional status of chickens, related to the function of red blood cells in supplying oxygen to all body cells for cellular metabolism. Increased oxygen demand results in increased erythroposis (formation of red blood cells) in the body

This research aims to determine the effect of the use of herbal feed additives on the profile of red blood. The benefit of this research is the empowerment of herbal medicine in livestock raising. The hypothesis of this study is the addition of herbal medicine is able to maintain the condition of the red blood profile under normal circumstances. 


\section{Materials and Methods}

The research on "The Effect of Additive (Herbal Medicine) on Red Blood Profile in Laying Hens" was carried out in June 2018 in 53 laying hens, Kendal.

The research material consisted of 40 layer laying hens, Lohmann Brown layer layer age of 35 weeks by being put in a battery cage, each unit of battery cage plot was filled with 2 birds. The study was designed using a completely randomized design, consisting of 4 treatments with 5 replays, so that there were 20 units of enclosure plots. The herbal medicine given is a mixture of temulawak, lempuyang, ginger, bitter and turmeric in the form of flour obtained from Bringharjo market, Yogyakarta. The herbal medicine is mixed with a certain amount of feed (according to the treatment dose). Equipment used includes scales to weigh feed, herbal medicine and eggs, thermohigrometers for measuring temperature and humidity inside and outside the cage, blood sample preparation equipment (syringe, vacutainer and cool box).

The implementation phase is done by adapting livestock to the environment and feed treatment and maintenance for 1 month. Feed is given little by little gradually so that laying hens can consume all the feed provided. Chickens were given ad libitum rations, rations were formulated to contain a minimum of $17.0 \%$ Protein, a minimum of $3 \%$ fat, a maximum of $6 \%$ Crude Fiber, a maximum Ash of 14\%, Calcium 3.5-4.0\%, a minimum Phospor of $0.45 \%$. The method of making rations is to mix the feed with herbal medicine. Herbs that are mixed with each feed have a population of $20 \%$ of each type, namely curcumin $20 \%$, ginger $20 \%$, ginger $20 \%$, bitter $20 \%$ and turmeric $20 \%$ and herbs mixed with feed have a certain dose that is, T1: feed mixed with $0.5 \%$ herbal medicine, T2: $1 \%$ and $\mathrm{T} 3: 1.5 \%$.

Data collection and analysis was carried out by taking 20 samples as samples, each 1 sample per replicate unit. Chicken samples are taken blood through the wing brachial vein using a syringe (syringe). Blood taken as much as $\pm 2 \mathrm{cc}$ is inserted into the vacumtainer containing EDTA anticoagulant (Ethylen Diamine Tetra Acetic Acid) shaken slowly until mixed so as not to clot. After that put in a thermos filled with ice. Then analyzed to determine the amount of erythrocytes, hemoglobin, hematocrit in the blood of laying hens.

The experimental design used was a completely randomized design (CRD), with 4 treatments and 5 replications so that there were 20 experimental units. The treatments used are:

T0 = laying hens are not given additional herbal medicine

$\mathrm{T} 1=$ laying hens given $0.5 \%$ additional herbal medicine

$\mathrm{T} 2=$ laying hens are given an additional herbal medicine of $1 \%$

$\mathrm{T} 3=$ laying hens given $1.5 \%$ additional herbal medicine

The data obtained were then analyzed using variance or F test, to determine the effect of the treatment continued with the Dual Region Test (Duncan) at the 5\% level.

\section{Results and Discussion}

The red blood profile of laying hens aged 39 weeks given the herbal treatment are presented in Table 1: 
Table 1. Average Red Blood Profile of Laying Hens Age 39 Weeks

\begin{tabular}{|c|c|c|c|c|}
\hline \multirow{2}{*}{ Parameters } & \multicolumn{4}{|c|}{ Treatment } \\
\hline & T0 & T1 & $\mathrm{T} 2$ & T3 \\
\hline Eritrosit (juta/dl) & 1.89 & 2.23 & 2.17 & 2.13 \\
\hline Hemoglobin (g/dl) & 8.5 & 10 & 9.4 & 9.1 \\
\hline Hematokrit $(\%)$ & $20^{\mathrm{b}}$ & $24.5^{\mathrm{a}}$ & $22.9^{\mathrm{ab}}$ & $22.2^{\mathrm{ab}}$ \\
\hline
\end{tabular}

Superscripts show very significant differences $(\mathrm{P}<0.05)$.

\section{Total Erythrocytes}

Statistical analysis did not show any significant effect $(\mathrm{P}>0.05)$ from the ration given the addition of herbal additives to the total erythrocytes in laying hens. The total number of erythrocytes obtained from the study ranged from 1.89-2.23 million / $\mathrm{mm} 3$. This value is included in the normal range of total erythrocyte values in aged broilers ranging from 2.17 to 2.86 million / $\mathrm{mm} 3$ (Talebi et al., 2005). The difference in the number of erythrocytes in the study was probably due to the nutrition provided and the temperature of the maintenance enclosure which was relatively the same between treatments. According to the statement of Piliang and Djojosoebagio (2016) that the factors that can influence the formation of erythrocytes include the adequacy of nutrition and maintenance environment temperature.

The average amount of erythrocytes in the normal range indicates that the body's metabolic processes and nutritional needs are fulfilled. Yuniwarti (2015) states that the amount of erythrocytes is influenced by nutrition, the higher the erythrocytes, the better it is because it shows that their nutritional needs are met. In addition to nutrition, maintenance environmental temperature is also one of the factors that influence the number of red blood cells in poultry. Isroli et al., (2009) states that high body temperature causes metabolic processes to decrease, resulting in higher erythrocyte performance, so that red blood cells die quickly. This will be balanced with the process of formation of red blood cells that increase.

\section{Hemoglobin levels}

Based on statistical analysis showed that there was no significant effect $(\mathrm{P}>0.05)$ on the levels of hemoglobin in laying hens that were given additional herbal additives. The average total hemoglobin yield from the study was $8.5-10 \mathrm{~g} / \mathrm{dl}$, the value is still in the normal range where the normal level of hemoglobin in chickens is $7.0-13.0 \mathrm{~g} / \mathrm{dl}$ (Jain, 1993). Hemoglobin is a component of erythrocytes that serves as an oxygen binding agent which if the number of erythrocytes decreases the hemoglobin level will also go down. Hemoglobin levels are positively correlated with the amount of erythrocytes. According to Weiss and Wardrop (2010), hemoglobin levels are influenced by oxygen demand and the number of erythrocytes so that there is a tendency if the number of erythrocytes is low, then hemoglobin levels will be low, Swenson (1993) states that in normal animals, hemoglobin levels are related to the number of erythrocytes and hematocrit levels. 
The addition of herbs in which there is a mixture of turmeric containing curcumin can stabilize hemoglobin levels in the blood. According to Chattopadhyay et al., (2014) turmeric contains curcumin which provides antioxidant effects that protect hemoglobin from oxidation. Hemoglobin levels in chickens can also be influenced by species, age, sex, environment and feed composition. It also can be caused by the condition of the cage, where the condition of the cage that is open all day causes the chickens to get enough oxygen. Fahmi et al., (2017) states that the amount of hemoglobin is influenced by the amount of oxygen and nutrients absorbed by the body for the erythropoetin process.

\section{Hematocrit levels}

The results of statistical analysis on blood hematocrit levels in laying hens showed a significant effect $(\mathrm{P}<0.05)$. The results in this study have a range of $20-24.5 \%$. These levels are still in the normal range where the percentage of hematocrit laying hens ranges between 22-35\% (Dharmawan, 2002). Hematocrit levels with the addition of herbal medicine in rations both at T1, T2 and T3 are different $(\mathrm{P}<0.05)$ with chickens that were not given additional herbal medicine in the ration. The addition of herbal medicine causes increased levels of erythrocytes so that the hematocrit value has increased. According to Winarsih (2005), hematocrit levels are very dependent on the number of erythrocyte cells, because erythrocytes are the largest cell mass in the blood.

Increased hematocrit value in the blood will have an impact on blood viscosity, which is blood viscosity. The greater the percentage of hematocrit, the more viscosity of the blood increases. According to Cunningham (2002) high hematocrit causes an increase that will slow down blood flow to the capillaries and accelerate the work of the heart. The thickening of the blood results in slowing of blood flow so that the oxygen distribution in the body of cattle also slows. Azhar (2017) states the hematocrit value is generally an indicator of determining the ability of blood to transport oxygen (O2) which is commonly known as Oxygen Carrying Capacity.

\section{Conclusion}

Based on the results of the research it can be concluded that the addition of herbal medicine in the form of a mixture of herbal ginger, lempuyang, ginger, bitter and turmeric at $0.5 \%$ level can increase the profile of red blood in laying hens. Suggestions for this research should be the use of herbs as feed additives must be done carefully because they can negatively impact the laying hen circulation system.

\section{References}

Azhar, A. D. 2017. Jumlah eritrosit, kadar hemoglobin dan nilai hematokrit pada ayam Bangkok, ayam kampung dan ayam peranakan. JIMVET. 01 (3) : 533-539. ISSN : 2540-9492.

Chattopadhyay, I., K. Biswaws., U. Bandyopadhyay, dan R. K. Banarjee. 2004.Turmeric and curcumin: Biological actions and medicinal applications. J. Current Science. 87 (2):44 53. 
Cunningham, J. G. 2002. Textbook of Veterinary Physiology. USA: Saunders Company.

Damayanti D. 2005. Pengaruh Penambahan Kunyit (Curcuma domestica Val.) atau Temulawak (Curcuma xanthorhiza Roxb) dalam Ransum Terhadap Persentase Karkas dan Potongan Karkas Komersial Broiler. Bogor: Fakultas Peternakan Institut Pertanian Bogor.

Dharmawan, N. S. 2002. Pengantar Patologi Klinik Veteriner. Hematologi Klinik. Universitas Udayana, Denpasar.

Fahmi, F.W., Widiastuti, E. and Sugiharto, S., 2017. The effect of feeding duration of Spirulina platensis in ration on red blood cells profile of broiler chicken. Jurnal Ilmu-Ilmu Peternakan. 27 (3): 54-62.

Isroli., S. Susanti, W. Widiastuti, T. Yudiarti, dan Sugiharto. 2009. Observasi beberapa variable hematologis ayam kedu pada pemeliharaan intensif. Seminar Nasional Kebangkitan Peternakann 2009. Fakultas Peternakan dan Pertanian Diponegoro, Semarang.

Jain, N. C. 1993. Essential of Veterinary Hematoloy. Lea and Febriger, Philadelphia.

Rahayu, I., T Sudaryani., H Santosa. 2011. Panduan Lengkap Ayam. Penebar Swadaya.Jakarta

Piliang, W. G. dan S, Djojosoebagio. 2006. Fisiologi Nutrisi, Vol. 2. Institut Pertanian Bogor Press. Bogor.

Swenson, M. J. 1993. Physiological Properties and Celluler and Chemical Constituent of Blood in Dukes Physiology of Domestic Animals, $11^{\text {th }}$ Ed. Comstock Publishing Associates a Division of Cornell University Press Ithaca and London, New York.

Talebi, A., S. A. Rezaei, R. R. Chai and R. Sahraei. 2005. Comparative studies on haematological value of broiler strains. Int. J. Poult. Sci., 4(8):573-579.

Weiss, D. J and K. J. Wadrop. 2010. Schalm's Veterinary Hematology. $6^{\text {th }}$ Ed.86 Blackwell Publishing Ltd, Oxford.

Winarsih, W. 2005. Pengaruh Probiotik dalam Pengendalian Slamonellosis Subklinis, Gambaran Patologis dan Performan pada Ayam. Institute Pertanian Bogor, Bogor.

Yuniwarti, E. Y. W. 2015. Profil darah ayam broiler setelah vaksinasi Ai dan pemberian berbagai kadar VCO. Bulletin Anatomi dan Fisiologi. 23 (1): 3846. 